\title{
The role of plant sociology in the study and management of European forest ecosystems
}

\author{
Carlo Blasi, Sabina Burrascano
}

Forest composition is a faithful indicator of the stressors and disturbances that influence forest ecosystems, and it should be accounted for in Sustainable Forest Management policies. Indeed, the classification of forest ecosystems in forest types is considered as a key tool to improve the assessment and monitoring of forest biological diversity, and for the definition of management guidelines. Accordingly, the Ministerial Conference on the Protection of Forests in Europe has recognized the need of developing a pan-European forest classification in forest types, and has identified indicators of Sustainable Forest Management that should be applied by forest types. The classification of vegetation has always been among the main aims of the plant sociology. The quantitative and qualitative analysis of plant species composition, performed through the plant sociological approach, condenses compositional and structural information within a hierarchical system, and expresses all historical, sociological and habitat factors that influence the actual and potential vegetation. In a modern perspective the integration of plant sociology and ecological analysis represents a key to a hierarchical land classification and to the understanding of vegetation dynamics; furthermore the long history of plant sociology determined the availability of large datasets of vegetation data throughout Europe. Starting from these considerations, in this paper we briefly describe how plant sociology could represent a tool for the assessment of the indicators of SFM that should be applied by forest types, giving insights on how this discipline could contribute to the assessment of each of these indicators.

Keywords: Forest Composition, Land Ecological Classification, Vegetation Dynamics, Indicators, Sustainable Forest Management

\section{Introduction}

\section{Natural and anthropogenic}

\section{determinants of forest attributes}

Forests are complex systems whose main attributes derive from the interplay of several abiotic and biotic factors. In addition to such factors, in the last millennia forests were altered by several human activities, especially intense and widespread in the temperate and Mediterranean zones of Europe, that

$\square$ Department of Environmental Biology, “La Sapienza" University of Rome, p.le Aldo Moro 5, I-00185, Rome (Italy)

\section{(a), Sabina Burrascano}

(sabinaburrascano@gmail.com)

Received: Nov 21, 2012 - Accepted: Dec 12, 2012

Citation: Blasi C, Burrascano S, 2013. The role of plant sociology in the study and management of European forest ecosys tems. iForest 6: 55-58 [online 2013-01-21] URL: http://www.sisef.it/iforest/contents? id=ifor0913-006

Communicated by: Marco Borghetti are, and always were, among the most densely populated regions globally. As a consequence, besides being determined by climatic, lithological and morphological drivers and by the regime of natural disturbances, the main attributes of most European forests are related to the type and intensity of past and current human management (Corona et al. 2010).

Many authors recognize, as the main attributes of forest ecosystems, composition, structure and function which are intimately related to each other (Franklin et al. 1981, Noss 1990, Marchetti et al. 2010).

Forest composition strongly depends on the regional and local species pool deriving from past geographical and climatic events; moreover, the distribution of species and communities along ecological gradients faithfully reflects the abiotic conditions of a site (Carni et al. 2011). These drivers interact with biotic factors (such as competition and facilitation) and with random events (Hubbell 2001). In addition to the mentioned determinants, forest composition was directly altered by human management, which caused a strong reduction of forests tree species richness in many regions, and partly hampered the spread of species that require long time for colonization (Hunter 1999, Verheyen et al. 2003).

Also forest structure and functions depend on biotic and abiotic features that determine for instance the productivity and natural disturbance processes in a given habitat. However, in managed systems, these attributes are directly manipulated to achieve productive objectives. Indeed, conventional forest management often influences stand developmental processes through the simplification of forest structure aimed at reaching the maximum potential biomass accumulation rate while neglecting other ecosystem functions (Ciancio \& Nocentini 2011). On the other hand, the life-history traits and the longevity of species in a forest directly influence forest structure, productivity, and dynamics.

Therefore, forest composition has a prominent role in the indication of the stressors and disturbances that influence forest ecosystems, and it should be accurately analyzed and substantially accounted for in Sustainable Forest Management policies (Blasi et al. 2010)

\section{The definition of forest types as a tool for Sustainable Forest Management} Sustainable Forest Management (SFM) is widely accepted as the overriding objective for forest policy and practice. The high level forest policies that address all dimensions of SFM are driven in the pan-European region by the Ministerial Conference on the Protection of Forests in Europe (MCPFE), that was the first to define the concept of SFM as: "the stewardship and use of forests and forest lands in a way, and at a rate, that maintains their biodiversity, productivity, regeneration capacity, vitality and their potential to fulfill, now and in the future, relevant ecological, economic and social functions, at local, national, and global levels, and that does not cause damage to other ecosystems". In order to evaluate and report on progress towards implementing SFM in the pan-European region, the Ministerial Conference on the Protection of Forests in Europe (MCPFE 2002) defined a set of criteria and indicators. The six criteria in which the indicators are classified define and characterize the essential elements by which SFM may be assessed. The periodical measurement of the indicators reveals the direction of change with respect to each criterion. The MCPFE countries report periodically on this basis, contributing to a report on the "State of Europe's forests" and on the progress towards sustainable forest management issued by MCPFE with the aim of providing policy and decision makers with key facts and figures about Europe's forests and SFM and to inform a wider public (UNECE-FAO 2011).

Among the mentioned indicators, seven 
Tab. 1 - Pan-European criteria and indicators of Sustainable Forest Management (SFM) based on forest types from EEA (2006).

\section{Forest type-based indicators} Criterion 1:
Forest resources
and global carbon cycles

\subsection{Forest area}

Area of forest and other wooded land, classified by forest type and by availability for wood supply,and share of forest and other wooded land in total land area

1.2 Growing stock Growing stock on forest and other wooded land, classified by forest type and by availability for wood supply

1.3 Age structure Age structure and/or diameter distribution of and/or diameter forest and other wooded land, classified by forest distribution type and by availability for wood supply

Criterion 2: $\quad$ 2.4 Forest damage $\quad$ Forest and other wooded land with damage, clas-

Forest health and

vitality

Criterion 4:

4.1 Tree species sified by primary damaging agent (abiotic, biotic and human induced) and by forest type

Forests biological composition diversity

Area of forest and other wooded land, classified by number of tree species occurring and by forest type

4.3 Naturalness Area of forest and other wooded land, classified by "undisturbed by man", by "semi-natural" or by "plantations", each by forest type

4.5 Deadwood Volume of standing deadwood and of lying deadwood on forest and other wooded land classified by forest type

were explicitly designed for an application by forest types (Tab. 1). These indicators are classified into three different criteria: forest resources and global carbon cycles; forest health and vitality; forest biological diversity; therefore, they are relevant to several different issues within the framework of SFM (EEA 2006).

In this view, the classification of forest ecosystems into homogeneous forest types is a valuable approach for the definition of management guidelines. Indeed, forest types are considered as a key tool for improving the assessment and monitoring of forest biological diversity in Europe. Accordingly, the MCPFE has officially recognized "the need of improving existing international forest classification, through developing a panEuropean understanding on forest classification in forest types" (MCPFE 2005).

\section{The role of plant sociology in the} definition of forest types

The classification of vegetation has at first been the focus of those geographers that in the XIX century investigated on the distribution of plants, like Alexander von Humboldt and Joachim Frederik Schouw, setting the scene for the first vegetation scientists. Among the earlier vegetation scientists some foresters are often mentioned since they used the plant sociological approach to define different forest types (see Cajander 1909, Sukatschew 1932). Indeed, vegetation science addresses the question of "What is the distribution of plants and the vegetation types they create, and which drivers determine this distribution?" (Pott 2011). Therefore, the classification of vegetation types have always been among the main topic of vegetation science, in particular qualitative and quantitative analysis of plant species composition has two kinds of advantages in the definition of vegetation types:

- the possibility of condensing compositional and structural information in vegetation types within a hierarchical system in which different levels can be used in relation to the degree of floristic similarity and to the scale of analysis;

- the resulting types will be the expression of all historical, sociological and habitat factors that influence the quality and quantity of vegetation.

A classification of vegetation types that reflects the whole set of conditions in which plant communities develop was among the main aims of plant sociology since its earliest steps. In a modern perspective the proper integration of plant sociology and ecological analysis represents a key to a hierarchical land classification that defines ecological units and vegetation types with a degree of detail depending on the scale of analysis (Blasi \& Frondoni 2011, Capotorti et al. 2012).

The long history of plant sociology not only provided this discipline with several different approaches (ecological and dynamic), but also determined the availability of large datasets of vegetation data throughout Europe. Plant sociological databases, that are increasingly being integrated at the European level, have a wide range of application: from the assessment of the diversity of plant communities (Feoli et al. 2011), to international initiatives in nature conservation, e.g., Natura2000 (Schaminee et al. 2011).

\section{Plant sociology and the indicators} of sustainable forest management

Given the wide relevance of plant sociology in the definition of forest types and in the application of compositional information to define several ecosystem parameters, we will here briefly describe how vegetation science, and especially plant sociology, could represent a means for the assessment of the indicators of SFM that should be applied by forest types.

\section{Forest area}

This indicator is based in the area of forest and other wooded land classified by forest type, therefore vegetation maps are particularly useful for a proper assessment. Such maps would be even more useful if the mapped vegetation types are associated with information on vegetation dynamic, and with data on the climate, lithology and morphology of the areas on which they develop. Indeed, through the plant sociological approach, it is possible to define models of vegetation dynamic (vegetation series) and to relate these to unique combinations of climatic, lithological and morphological conditions. Such a great body of information can be achieved using jointly the inductive methodology of plant sociology (based on field observations and data collection) and the deductive approach of landscape ecology that identifies ecologically homogenous land units through a process of hierarchical classification (Blasi et al. 2005).

\section{Growing stock}

According to the MCPFE scheme, the indication of growing stock should be classified by forest type and by availability of wood supply. Again the use of detailed vegetation maps could effectively be the starting point to define associations between some ecosystem parameters, such as biomass, and specific forest types, as it was already proposed for grasslands (Poldini et al. 2011), while today classifications based solely on the dominant species are used (Marchetti et al. 2012). The use of vegetation maps based on forest types with detailed information on composition instead of maps based on dominant tree species will also contribute to the assessment of the indicator "tree species composition" (4.1 in Tab. 1).

Moreover, the definition of dynamic models specific to each vegetation type (vegetation series) could help in the management of forest areas, with special reference to the "other wooded lands", that may include 
areas that will develop into forests with a high potential for biomass accumulation.

\section{Age structure}

The age structure of a stand is highly informative with regards to its degree of heterogeneity that strongly affects the levels of biological diversity for numerous taxonomic groups. The plant sociological approach could integrate the analysis of stand ages, for instance with regards to those age classes considered particularly valuable for the maintenance of forest biological diversity, such as old-growth forests. This approach was already applied in Italian national parks, where a network of old-growth forests was defined that represents, as closely as possible, all the forest types occurring in the national parks differing in ecological and phytogeographic features based on the map of the vegetation series. This network represented a starting point for further investigations aimed at identifying sustainable management guidelines, especially in terms of biological diversity (see Ricotta et al. 2010 and references therein).

\section{Forest damage}

Also in relation to forest damage, regardless of the nature of the damaging agent, it is important to have a sound knowledge of the community occurring in the damaged area, and of the communities that are most likely to replace it. Indeed information about the model of vegetation dynamic (vegetation series) will allow to interpret ecologically and in a dynamic perspective the communities developing after a damage and to define management actions consistent with the current vegetation conditions and with their potential to restore the former community (Blasi et al. 2005).

\section{Naturalness}

The concept of naturalness is used for systems not created or influenced by man (Angermeier 2000). In the description of ecosystems, "natural" is generally used in contrast to "artificial"; as a consequence, naturalness expresses a gradient between these extremes (Machado 2004). In order to place systems along this gradient many authors used criteria based on the history and the potentiality of a site (Anderson 1991, Angermeier 2000). Indeed, in most areas that are potentially covered by forests, human influence on natural dynamic has been substantial, making difficult to identify sites where this influence was negligible (Acosta et al. 2000, Ricotta et al. 2001).

In this view the use of the plant sociology, taking advantage also of a deductive approach, can effectively drive the assessment of the level of naturalness, through the analysis of the consistency between the real and the potential vegetation of a site.

\section{Deadwood}

Deadwood volumes strongly depend on the stand disturbance regime, therefore also on the type and intensity of management. Nevertheless, further determinants of the amount of deadwood that could be found in a forest are: (i) climate, especially temperature, that was reported as the main driver of deadwood decay rates in a global analysis (Mackensen et al. 2003); (ii) tree species composition, since wood decomposition rates are species-specific and strongly depend on species traits (Cornwell et al. 2009, Zell et al. 2009). Therefore a thorough knowledge of the vegetation composition and its relations to climate would effectively integrate quantitative analysis on deadwood.

\section{Conclusions}

We highlighted how plant sociology, through a dynamic and integrated approach, may support the study and management of forest ecosystems. Indeed, the understanding of such complex systems could be achieved through a multidisciplinary approach that could inform on forest structure, composition and functions. Plant sociology, integrating information on forests' current and potential composition is extremely useful for qualitative and quantitative analysis aimed at conservation programs, as well as at the definition of sustainable management guidelines.

\section{References}

Acosta A, Blasi C, Stanisci A (2000). Spatial connectivity and boundary patterns in coastal dune vegetation in the Circeo National Park, Central Italy. Journal of Vegetation Science 11: 149-154. - doi: 10.2307/3236787

Anderson JE (1991). A conceptual framework for evaluating and quantifying naturalness. Conservation Biology 5: 347-352. - doi: 10.1111/j. 1523-1739.1991.tb00148.x

Angermeier PL (2000). The natural imperative for biological conservation. Conservation Biology 14: 373-381. - doi: 10.1046/j.1523-1739.2000. 98362.x

Blasi C, Frondoni R (2011). Modern perspectives for plant sociology: The case of ecological land classification and the ecoregions of Italy. Plant Biosystems 145: 30-37. - doi: 10.1080/11263504 .2011 .602747

Blasi C, Capotorti G, Frondoni R (2005). Defining and mapping typological models at the landscape scale. Plant Biosystems 139: 155-163. - doi: 10.1080/11263500500163629

Blasi C, Marchetti M, Chiavetta U, Aleffi M, Audisio P, Azzella MM, Brunialti G, Capotorti G, Del Vico E, Lattanzi E, Persiani AM, Ravera S, Tilia A, Burrascano S (2010). Multi-taxon and forest structure sampling for identification of indicators and monitoring of old-growth forest. Plant Biosystems 144: 160-170. - doi: 10.1080/ 11263500903560538

Cajander AK (1909). Über Waldtypen. Acta Botanica Fennica 28, Helsingfors, Finland.
Capotorti G, Guida D, Siervo V, Smiraglia D, Blasi C (2012). Ecological classification of land and conservation of biodiversity at the national level: the case of Italy. Biological Conservation 147: 174-183. - doi: 10.1016/j.biocon.2011.12. 028

Carni A, Juvan N, Kosir P, Marinsek A, Pausic A, Silc U (2011). Plant communities in gradients. Plant Biosystems 145: 54-64. - doi: 10.1080/ 11263504.2011.602730

Ciancio O, Nocentini S (2011). Biodiversity conservation and systemic silviculture: concepts and applications. Plant Biosystems 145: 411-418. doi: 10.1080/11263504.2011.558705

Cornwell WK, Cornelissen JHC, Allison SD, Bauhus J, Eggleton P, Preston CM, Scarff F, Weedon JT, Wirth C, Zanne AE (2009). Plant traits and wood fates across the globe: rotted, burned, or consumed? Global Change Biology 15: 2431-2449. - doi: 10.1111/j.1365-2486.2009 $.01916 . \mathrm{x}$

Corona P, Blasi C, Chirici G, Facioni L, Fattorini L, Ferrari B (2010). Monitoring and assessing old-growth forest stands by plot sampling. Plant Biosystems 144: 171 - 179. - doi: 10.1080/112 63500903560710

EEA (2006). European forest types - categories and types for sustainable forest management reporting and policy. Technical report No 9/2006, European Environment Agency, Copenhagen, Denmark, pp. 114. [online] URL: http://www. eea.europa.eu/publications/technical_report_200 69

Feoli E, Ganis P, Venanzoni R, Zuccarello V (2011). Toward a framework of integrated knowledge of terrestrial vegetation system: the role of databases of phytosociological releves. Plant Biosystems 145: 74-84. - doi: 10.1080/11263504 .2011 .602739

Franklin JF, Cromack K, Denison W, McKee A, Maser C, Sedell J, Swanson F Juday G (1981). Ecological characteristics of old-growth Douglas-fir forests. General Technical Report PNW-118, US Department of Agricolture, Portland, OR, USA.

Hubbell SP (2001). The unified neutral theory of biodiversity and biogeography. Princeton University Press, Princeton, NJ, USA.

Hunter ML (1999). Maintaining biodiversity in forest ecosystems (Hunter ML ed). Cambridge University Press, Cambridge, UK.

Machado A (2004). An index of naturalness. Journal of Nature Conservation 12: 95-110. doi: 10.1016/j.jnc.2003.12.002

Mackensen J, Bauhus J, Webber E (2003). Decomposition rates of coarse woody debris - a review with particular emphasis on Australian tree species. Australian Journal of Botany 51: 27-37. - doi: 10.1071/BT02014

Marchetti M, Tognetti R, Lombardi F, Chiavetta U, Palumbo G, Sellitto M, Colombo C, Iovieno P, Alfani A, Baldantoni D, Barbati A, Ferrari B, Bonacquisti S, Capotorti G, Copiz R, Blasi C (2010). Ecological portrayal of old-growth forests and persistent woodlands in the Cilento and Diano National Park (southern Italy). Plant Bio- 
systems 144: 130-147. - doi: 10.1080/112635 00903560470

Marchetti M, Sallustio L, Ottaviano M, Barbati A, Corona P, Tognetti R (2012). Carbon sequestration by forests in the national parks of Italy. Plant Biosystems 146 (4): 1001-1011. - doi $10.1080 / 11263504.2012 .738715$

MCPFE (2002). Improved pan-European indicators for sustainable forest management. MCPFE Expert Level Meeting, Vienna (Austria) 7-8 October 2002. MCPFE, Liason Unit, Vienna, Austria. [online] URL: http://www.foresteurope.org/ docs/reporting/Vienna_Improved_Indicators.pdf MCPFE (2005). MCPFE work programme. Ministerial Conference on the Protection of Forests in Europe, Liason Unit, Warsaw, Poland, pp. 56 [online] URL: http://www.foresteurope.org/documentos/mcpfe_work_cor3.pdf

Noss NF (1990). Indicators for monitoring biodiversity - a hierarchical approach. Conservation Biology 4: 355-364. - doi: 10.1111/j.15231739.1990.tb00309.x

Poldini L, Sburlino G, Buffa G, Vidali M (2011).
Correlations among biodiversity, biomass and other plant community parameters using the phytosociological approach: a case study from the south-eastern Alps. Plant Biosystems 145: 131-140. - doi: 10.1080/11263504.2010.547673 Pott R (2011). Phytosociology: a modern geobotanical method. Plant Biosystems 145: 9-18. doi: 10.1080/11263504.2011.602740

Ricotta C, Celesti Grapow L, Avena G, Blasi C (2001). Topological analysis of the spatial distribution of plant species richness across the city of Rome (Italy) with the echelon approch. Landscape and Urban Planning 57: 69-76. - doi: 10.1016/S0169-2046(01)00187-6

Ricotta C, Burrascano S, Blasi C (2010). Incorporating functional dissimilarities into sampledbased rarefaction curves: from taxon resampling to functional resampling. Journal of Vegetation Science 21: 280-286. - doi: 10.1111/j.16541103.2009.01142.x

Schaminee JHJ, Janssen JAM, Hennekens SM, Ozinga WA (2011). Large vegetation databases and information systems: new instruments for ecological research, nature conservation, and policy making. Plant Biosystems 145: 85-90. doi: 10.1080/11263504.2011.602744

Sukatschew WN (1932). Die Untersuchung der Waldtypen des osteuropäischen Flachlandes. In "Handbuch biol". Arbeitsmethoden 379, Berlin, Germany.

UNECE-FAO (2011). State of Europe's Forests. Ministerial Conference on the Protection of Forests in Europe, Liaison Unit, Oslo, Norway. [online] URL: http://www.unece.org/forests/fr/outputs/soef2011.html

Verheyen K, Guntenspergen GR, Biesbrouck B, Hermy M (2003). An integrated analysis of the effects of past land use on forest herb colonization at the landscape scale. Journal of Ecology 91: 731-742. - doi: 10.1046/j.1365-2745.2003. 00807.x

Zell J, Kandler G, Hanewinkel M (2009). Predicting constant decay rates of coarse woody debris - a meta-analysis approach with a mixed model. Ecological Modelling 220: 904-912. - doi: 10.1016/j.ecolmodel.2009.01.020 